\title{
KEMAMPUAN PENILIK DALAM MELAKSANAKAN TUGAS POKOK DITINJAU DARI KEPUTUSAN MENPAN NO.15/KEP/MENPAN/3/2002
}

\author{
Baso Intang Sappaile
}

\begin{abstract}
The decentralization policy stipulated in the Constitution of Number 22 of 1999 gives impact to many aspects of government management including in education. This research investigates the assessor's competence in implementing their main tasks based on the decree of Number 15/KEP/ MENPAN/3/2002 and the obstacles in implementing the decree.

The research conducted in East Java covering four districts used qualitative approach and the data were collected by interview and document study. The result of this research concludes that the assessor's competence has not completely met the requirements stated in the Minister's decree. Local government has given support in implementing the Minister's decree. However, the problems faced include the lack of assessors' competences, unclear criteria for professional assessor's formation based on work load, and the inability of the assessors to count their working credits.
\end{abstract}

Keywords: out of school education, assessors, competence,

\section{PENDAHULUAN}

Diberlakukannya Undang-Undang No. 22 Tahun 1999 tentang Pemerintahan Daerah memberikan implikasi yang luas dalam berbagai bidang pemerintahan, antara lain terjadinya perubahan tugas dan fungsi serta kewenangan pembinaan kelembagaan dan ketenagaan di bidang pendidikan luar sekolah dan pemuda. Salah satu perubahan tersebut adalah kewenangan dalam rangka pembinaan dan pemberdayaan tenaga kependidikan luar sekolah dan pemuda dari pemerintah pusat kepada pemerintah daerah.

Sejalan dengan itu, Direktorat Jenderal Pendidikan Luar Sekolah dan Pemuda (Ditjen Diklusepa) telah melakukan penyesuaian status, tugas dan fungsi tenaga kependidikan luar sekolah, khususnya pengalihfungsian jabatan penilik dan jabatan struktural menjadi jabatan fungsional penilik yang diatur dengan Keputusan Menteri Negara Pendayagunaan Aparatur Negara (Menpan) Nomor 15/KEP/MENPAN/ 3/2002 tentang Jabatan Fungsional Penilik dan Angka Kreditnya. Dengan itu diharapkan penilik dapat menjadi tenaga yang profesional dalam rangka peningkatan pelayanan pendidikan luar sekolah dan pemuda kepada masyarakat.

Sejak diberlakukannya Kepmenpan tersebut, sampai saat ini belum diketahui sejauhmana pemahaman, kesiapan administrasi dan teknis, sikap Penilik, sikap masyarakat dan stakeholder terkait sehubungan dengan jabatan fungsional Penilik.

Tujuan penelitian ini adalah (1) untuk mendapatkan informasi secara komprehensif mengenai kemampuan penilik dalam melaksanakan tugas pokok berdasarkan Keputusan Menpan No.15/KEP/MENPAN/ $3 / 2002$, dan (2) untuk mengetahui penghambat pelaksanaan Keputusan Menpan No.16/KEP/MENPAN/ 3/2002 tentang Jabatan Fungsional Penilik dan Angka Kreditnya. Permasalahan yang dikaji adalah:

1. Sejauh mana kemampuan penilik dalam melaksanakan tugas pokok berdasarkan Keputusan Menpan Nomor 15/Kep/MENPAN/3/ 2002 tentang Jabatan Fungsional Penilik dan Angka Kreditnya?

2. Faktor-faktor apa saja yang menghambat pelaksanaan Keputusan tersebut?

\section{KAJIAN TEORITIS}

\section{Pendidikan Luar Sekolah}

Pendidikan adalah usaha sadar dan terencana untuk mewujudkan suasana beiajar dan proses pembelajaran agar peserta didik secara akfif mengembangkan potensi dirinya untuk memiliki

* Dosen Universitas Negeri Makasar kekuatan spiritual keagamaan, pengendalian diri, kepribadian, kecerdasan, akhlak mulia, serta keterampilan yang diperlukan dirinya, masyarakat bangsa dan negara (UUSPN, Pasal 1, ayat 1).

Dalam Undang-Undang Republik Indonesia No. 20 Tahun 2003 tentang Sistem Pendidikan Nasional Pasal 13 (1) dinyatakan bahwa pendidikan dapat 
dilaksanakan melalui tiga jalur yaitu pendidikan formal, nonformal dan informal untuk saling melengkapi dan memperkaya.

Pendidikan nonformal adalah jalur pendidikan di luar pendidikan formal yang dapat dilaksanakan secara terstruktur dan berjenjang (UUSPN, Pasal 1, ayat 12). Selanjutnya, dinyatakan bahwa pendidikan nonformal berfungsi sebagai pelengkap pendidikan formal dalam rangka mendukung pendidikan sepanjang hayat serta mengembangkan potensi peserta didik dengan penekanan pada penguasaan pengetahuan dan keterampilan fungsional serta pengembangan sikap dan kepribadian profesional (UUSPN, Pasal 26, ayat 2).

Dalam konteks pembelajaran program pendidikan nonformal sasarannya jelas yaitu diarahkan pada pengembangan 4 (empat) pilar : (1) learning to know, (2) learning to do, (3) learning to live together, dan (4) learning to be.

\section{Kelembagaan}

Dalam rangka memberikan dukungan terhadap pelayanan pendidikan nonformal (Pendidikan Luar Sekolah) kepada masyarakat, Departemen Pendidikan Nasional memberikan tanggung jawab kepada Direktorat Jenderal Pendidikan Luar Sekolah dan Pemuda (Ditjen Diklusepa) untuk menangani program-program pendidikan luar sekolah di dalam melaksanakan tugas dan fungsinya Ditjen Diklusepa membawahi empat Direktorat dan satu Sekretariat Ditjen, yaitu: (1) Direktorat Pendidikan Masyarakat, (2) Direktorat Kepemudaan, (3) Direktorat Pendidikan Anak Usia Dini, dan (4) Direktorat Tenaga Teknis.

Di samping empat Direktorat itu, Ditjen Diklusepa juga memiliki Unit Pelaksana Teknis (UPT) yaitu: Balai Pengembangan Pendidikan Luar Sekolah dan Pemuda (BPPLSP) seperti: BPPLSP regional I Sumatera Utara, BPPLSP regional II Jawa Barat, BPPLSP regional III Jawa Tengah, BPPLSP regional IV Jawa Timur, dan BPPLSP regional $\checkmark$ Sulawesi Selatan. Pada tingkat Provinsi program pendidikan luar sekolah ditangani oleh Kantor Dinas Pendidikan Provinsi, dalam hal ini Subdin PLS. UPT yang berada pada tingkat provinsi yang menangani pengembangan pendidikan luar sekolah dinamakan Balai Pengembangan Kegiatan Belajar (BPKB). Sejak adanya otonomi daerah nama BPKB ini ada yang berubah sesuai dengan kebijakan Pemda masingmasing. Pada tingkat kabupaten/kota, program pendidikan luar sekolah ditangani oleh Kantor Dinas Pendidikan kabupaten/kota, dalam hal ini Subdin PLSP. UPT yang berada pada tingkat kabupaten/ kota dinamakan Sanggar Kegiatan Belajar.

\section{Ketenagaan}

Untuk mendukung keberhasilan pelaksanaan program-program pendidikan luar sekolah, pemuda dan olah raga di lapangan diperlukan tenaga kependidikan yang handal. Menurut Undang-Undang No.20 Tahun 2003 tentang Sistem Pendidikan Nasional, tenaga kependidikan adalah anggota masyarakat yang mengabdikan diri dan diangkat untuk menunjang penyelenggaraan pendidikan.

Tenaga kependidikan berhak memperoleh: (1) penghasilan dan jaminan kesejahteraan sosial yang pantas dan memadai; (2) penghargaan sesuai dengan tugas dan prestasi kerja; (3) pembinaan karir sesuai dengan tuntutan pengembangan kualitas; (4) perlindungan hukum dalam melaksanakan tugas dan hak atas hasil kekayaan intelektual; dan (5) kesempatan untuk menggunakan sarana, prasarana dan fasilitas pendidikan untuk menunjang kelancaran pelaksanaan tugas. Dalam penjelasan UndangUndang itu disebutkan bahwa tenaga kependidikan meliputi pengelola satuan pendidikan, penilik, pamong belajar, pengawas, peneliti, pengembang, pustakawan, laboran, dan teknisi sumber belajar.

Dalam pendidikan nonformal petugas lapangan yang merupakan ujung tombak dalam menunjang keberhasilan program PLS adalah pamong belajar dan penilik yang keduanya merupakan tenaga fungsional. Pamong belajar adalah Pegawai Negeri Sipil (PNS) yang diberi tugas, tanggung jawab, wewenang dan hak secara penuh oleh pejabat yang berwenang untuk melaksanakan kegiatan belajar mengajar dalam rangka pengembangan model dan pembuatan percontohan serta penilaian untuk pengendalian mutu dan dampak pelaksanaan program pendidikan luar sekolah, pemuda dan olah raga.

Pamong belajar berkedudukan sebagai pelaksana teknis fungsional pengembangan model, 
pengajaran, dan penilaian pada Balai Pengembangan Kegiatan Belajar atau Sanggar Kegiatan Belajar. Tugas pokok pamong belajar adalah: (1) melaksanakan pengembangan model program pendidikan luar sekolah pemuda dan olahraga; (2) melaksanakan kegiatan belajar mengajar dalam rangka pengembangan model dan pembuatan percontohan program pendidikan luar sekolah, pemuda dan olahraga; dan (3) melaksanakan pemantauan dalam rangka pengendalian mutu dan dampak pelaksanaan program pendidikan luar sekolah, pemuda dan olah raga.

Penilik adalah PNS yang diberi tanggung jawab, wewenang, dan hak secara penuh oleh pejabat yang berwenang untuk melakukan kegiatan penilikan pendidikan luar sekolah yang selanjutnya disingkat dengan PLS, yang meliputi pendidikan masyarakat, kepemudaan, pendidikan anak dini usia dan keolahragaan. Penilik berkedudukan sebagai pelaksana teknis fungsional penilikan PLS pada Dinas Pendidikan kabupaten/kota atau Dinas yang bertanggung jawab di bidang PLS. Tugas pokok penilik adalah merancanakan, melaksanakan, menilai, membimbing, dan melaporkan kegiatan penilikan PLS.

\section{Jabatan Fungsional}

Seiring dengan peningkatan profesionalisme PNS, sistem pengangkatan PNS dalam jabatan fungsional disesuaikan kembali agar dapat lebih berdaya guna dan berhasil guna dalam memberikan pelayanan yang sesuai dengan tingkat kepuasan masyarakat. Dalam rangka upaya tersebut maka pelaksanaan pembinaan PNS dilakukan atas dasar sistem prestasi kerja dan sistem karir yang dititik beratkan pada sistem prestasi kerja.

Dalam Peraturan Pemerintah Republik Indonesia No. 99 Tahun 2000 tentang Kenaikan Pangkat Pegawai Negeri Sipil, pada Bab I Pasal 1, disebutkan hanya ada dua jenis jabatan yakni jabatan struktural dan jabatan fungsional. Jabatan struktural adalah suatu kedudukan yang menunjukkan tugas, tanggung jawab, wewenang, dan hak seorang PNS dalam rangka memimpin suatu satuan organisasi negara. Sedangkan yang dimaksud dengan jabatan fungsional adalah kedudukan yang menunjukkan tugas, tanggung jawab, wewenang, dan hak seorang PNS dalam rangka menjalankan tugas pokok dan fungsi keahlian atau keterampilan untuk mencapai tujuan organisasi.

Keputusan Menpan No. 15/KEP/MENPAN/3/ 2002 menyebutkan bahwa penilik merupakan jabatan fungsional, yang terdiri atas penilik terampil dan penilik ahli. Untuk menjaga kualitas dan pengendalian mutu program PLS maka kualifikasi pengangkatan ke dalam jabatan fungsional penilik adalah bidang kependidikan yang sesuai dengan tugas pokok penilik, yaitu: merencanakan, melaksanakan, menilai, dan melaporkan kegiatan penilikan PLS.

Selain persyaratan tersebut di atas, pengangkatan jabatan fungsional penilik juga harus sesuai dengan formasi jabatan fungsional penilik yang ditetapkan oleh Menpan setelah mendapatkan pertimbangan teknis dan Kepala BKN. Sebelum ada penetapan formasi jabatan fungsional penilik oleh Menpan, pengangkatan penilik didasarkan atas perhitungan antara beban kerja dengan jumlah penilik sesuai dengan jenjang jabatannya. Dalam hal ini, penilik yang diangkat diharapkan dapat melaksanakan kegiatan kepenilikan sehingga yang bersangkutan dapat memenuhi angka kredit kumulatif minimal untuk kenaikan pangkat/jabatannya. Ketentuan yang harus dipenuhi untuk itu ialah sekurang-kurangnya $80 \%$ angka kredit berasal dari unsur utama dan sebanyakbanyaknya $20 \%$ angka kredit berasal dari unsur penunjang. Pengangkatan penilik di setiap kecamatan berdasarkan jumlah desa dengan menggunakan rasio kurang lebih dari 5 (lima) desa dapat diangkat 1 (satu) orang penilik atau disesuaikan kebutuhan daerah. Syarat berikutnya memenuhi angka kredit minimal yang ditentukan untuk jenjang jabatannya.

Kategori penilaian angka kredit penilik sudah tertuang dan diatur dalam Keputusan Menpan No. 15/ MENPAN/3/2002 yang terdiri atas unsur utama dan unsur penunjang. Unsur utama adalah pendidikan, penilikan PLS dan pengembangan profesi. Sedangkan unsur penunjang adalah pengabdian pada masyarakat dan pendukung tugas penilikan PLS.

Dalam melakukan penilaian, Tim Penilai Angka Kredit perlu memahami unsur-unsur yang dinilai secara tepat dan obyektif. Guna menghindari adanya subyektivitas dalam melakukan penilaian, Tim Penilai harus menghilangkan hallo effect dan menghindari penilaian yang ekstrim, bersikap lunak dan "murah hati", bersikap keras dan prasangka pribadi sehingga kenaikan pangkat penilik tidak tarhambat.

\section{Kemampuan Profesional}

Kemampuan (ability) adalah kapasitas seorang individu untuk mengerjakan berbagai tugas dalam suatu pekerjaaan (Robbins 1998:46). Sedang Gibson (1985: 60) menyatakan bahwa kemampuan dapat dikatakan sebagai sesuatu yang dapat dipelajari ataupun yang dibawa sejak lahir yang memungkinkan seseorang menyelesaikan pekerjaannya. Pendapat lain, Cronbach (1970: 35) menyatakan bahwa kemampuan merupakan suatu penampilan maksimum (maximum performance). 
Berdasarkan beberapa pengertian di atas, dapat dikatakan bahwa kemampuan adalah suatu sifat atau kapasitas (pengetahuan dan keterampilan) yang dibawa sejak lahir oleh seorang individu atau dipelajari, yang memungkinkan seseorang untuk tampil secara maksimal dalam menyelesaikan pekerjaannya.

Dalam kenyataan yang dijumpai dapat dilihat bahwa kemampuan setiap orang tidaklah sama, ada orang-orang tertentu memiliki kemampuan lebih unggul dan di atas orang lain. Meskipun setiap orang memiliki kemampuan bawaan yang melekat pada otaknya, namun apabila kemampuan itu tidak dirangsang dan dikembangkan sebagaimana mestinya, maka hasilnya tidak akan memuaskan

Profesi adalah bidang pekerjaan yang dilandasi pendidikan keahlian (keterampilan kejujuran dan sebagainya) yang tertentu. Sedangkan pengertian profesional merupakan bidang pekerjaan yang memerlukan kepandaian khusus untuk menjalankannya. Dengan demikian yang dimaksud dengan kemampuan profesional ialah kapasitas (pengetahuan dan keterampilan) yang dituntut oleh suatu bidang pekerjaan yang memungkinkan seseorang untuk tampil secara maksimal dalam menyelesaikan pekerjaannya

Kriteria profesionalisme adalah: (1) adanya systematic body of knowledge, (2) adanya kewenangan profesional yang didasarkan atas senioritas dalam keahlian dan keterampilan, (3) adanya sanksi sosial dan pengakuan terhadap kewenangan. Sanksi dijatuhkan oteh organisasi profesi yang berfungsi mengendalikan dan mengawasi anggotanya. Organisasi profesi juga berfungsi untuk menyeleksi anggota baru, menetapkan akreditasi tingkat profesionalisme, menerbitkan perizinan, (4) memiliki kode etik, dan (5) budaya kerja yang khas bagi profesi bersangkutan atau profesional culture.

Penilik sebagai tenaga fungsional memiliki standar kemampuan profesional dalam bentuk struktur tugas pokok sebagaimana diatur di dalam Keputusan Menpan No.15/MENPAN/3/2002. Sukses atau tidaknya mereka menjalankan tugas pokoknya dipengaruhi oleh berbagai faktor tersebut di atas. Apabila dilihat dari rincian tugas yang harus dilaksanakan, penilik harus memiliki kemampuan:

1. membuat rencana,

2. melaksanakan program PLS,

3. melakukan analisis dan penilaian PLS,

4. melaksanakan bimbingan peningkatan mutu PLS,

5. menyusun laporan dan penilaian hasil Penilikan PLS,

6. pembuatan karya tulis di bidang pendidikan,

7. penemuan teknologi tepat guna di bidang pendidikan, dan
8. penyusunan petunjuk pelaksanaan penilikan PLS.

Pokok-pokok kemampuan seperti yang tersebut di atas merupakan syarat-syarat yang jelas pada jabatan profesional penilik. Dengan demikian, syaratsyarat di atas dapat dijadikan organisasi sebagai syarat dalam merekrut dan menyeleksi tenaga-tenaga yang cakap dan mampu merencanakan pendidikan dan latihannya. Kerancuan yang sering terjadi dalam pendidikan dan pelatihan pegawai diakibatkan oleh perencanaan diklat yang tidak pernah didasarkan atas analisis jabatan, sehingga setiap penyelenggaraan diklat tidak ada kaitannya dengan kebutuhannya. Melalui analisis jabatan upaya mengembangkan profesionalisme akan lebih mudah dilakukan, yang pada hakikatnya bertujuan untuk membentuk pegawaipegawai yang terampil dan berkeahlian.

\section{Kronologis Terbitnya Keputusan Menpan No. 15/ KEP/MENPAN/3/2002}

Sejak Undang-Undang No. 22 Tahun 1999 tentang Pemerintahan Daerah ditetapkan maka mulai saat itu diberlakukan desentralisasi yang ditandai dengan adanya penyerahan wewenang dan pemerintah pusat kepada pemerintah daerah dalam rangka otonomi yang luas, nyata dan bertanggung jawab. Selanjutnya Undang-Undang tersebut menyatakan bahwa kewenangan pemerintah pusat adalah penetapan persyaratan akreditasi lembaga pendidikan dan sertifikasi tenaga profesional ahli serta persyaratan jabatan, pembinaan dan pemberdayaan sumber daya manusia.

Untuk memantapkan pelaksanaan desentralisasi maka diterbitkan juga Peraturan Pemerintah No. 25 Tahun 2000 tentang Kewenangan Pemerintah dan Kewenangan Provinsi sebagai Daerah Otonom. Berkaitan dengan hal itu, timbul berbagai implikasi terhadap daerah dan implikasi yang paling nyata adalah perubahan pada struktur organisasi, perubahan kualitas dan kuantitas PNS, perubahan penataan dan penempatan kembali PNS sesuai dengan kompetensi dan kebutuhan organisasi, juga perubahan tata kerja dan prosedur kerja pelayanan publik, serta peningkatan peran jabatan fungsional dalam menjalankan fungsi dan tugasnya.

Selain kedua peraturan di atas, masih ada peraturan baru yakni Peraturan Pemerintah No. 84 Tahun 2000 tentang Pedoman Organisasi Perangkat Daerah, yang salah satu pasalnya menyebutkan adanya penghapusan jabatan eselon V. Hal ini menimbulkan permasalahan baru bagi penilik, karena penilik pada saat itu menduduki jabatan eselon V, sehingga harus dihapus. Masalah tersebut bukan hanya

Jurnal IImiah VISI PTK-PNF - Vol. 2, No.1 - $2007 \quad 67$ 
menjadi masalah bagi penilik namun juga menjadi masalah nasional bagi Ditjen Diklusepa.

Besarnya jumlah sasaran PLS dibandingkan dengan kecilnya jumlah tenaga lapangan, mengakibatkan jumlah ketenagaan sangat tidak seimbang, apalagi bila penilik ditiadakan. Hal yang demikian akan menimbulkan kesulitan baru bagi Ditjen Diklusepa dalam memberikan layanan pendidikan bagi masyarakat dan menjaga kualitas program PLS. Oleh karena itu, Ditjen Diklusepa mengambil suatu inisiatif untuk mengatasi masalah dengan cara melakukan koordinasi dengan Biro Kepegawaian Depdiknas, Badan Kepegawaian Nasional dan Menteri Pendaya- gunaan Aparatur Negara untuk segera membuat suatu Surat Keputusan guna mempertahankan penilik sebagai tenaga kependidikan yang menangani pendidikan luar sekolah.

Selanjutnya, pada tanggal 21 Maret 2002, ditetapkan alih fungsi penilik dari jabatan struktural menjadi jabatan fungsional melalui Keputusan Menpan No. 15/KEP/MENPAN/3/2002. Untuk mendukung dan memperlancar implementasi kebijakan tersebut maka ditetapkan Keputusan Bersama Mendiknas dan Kepala BKN No. I/U/SKB/2002 dan No. 4 Tahun 2002, tanggal 27 Maret 2002 tentang Petunjuk Pelaksanaan Jabatan Fungsional Penilik dan Angka Kreditnya.

\section{METODOLOGI PENELITIAN}

Provinsi yang menjadi tempat penelitian adalah Jawa Timur dengan 4 (empat) kabupaten/kota, yaitu: 2 (dua) kabupaten/kota yang peniliknya sudah impassing dan 2 (dua) kabupaten/kota yang peniliknya belum impassing.

Penelitian ini menggunakan pendekatan kualitatif. Pendekatan kualitatif dimaksudkan untuk menggali informasi lebih dalam dan seksama sehubungan dengan implementasi Keputusan Menpan No.15/KEP/MENPAN/3/2002 tentang Jabatan Fungsional Penilik dan Angka Kreditnya.
Subyek yang dijadikan sumber informasi terdiri atas Kepala Badan Kepegawaian Daerah (BKD), Kasubdin PLS, penilik yang sudah dan yang belum impassing, masyarakat (Penyelenggara Program Diklusepa).

Teknik pengumpulan data dilakukan dengan wawancara dan studi dokumentasi. Dalam pelaksanaan wawancara, pewawancara menggunakan pedoman wawancara dan dilakukan secara tatap muka, dan interaktif.

\section{HASIL PENELITIAN}

\section{Kemampuan Penilik dalam Melaksanakan Tugas Pokok}

Kemampuan penilik dalam melaksanakan tugas pokok sesuai dengan Keputusan Menpan belum memadai. Di samping itu, belum ada konsekuensi hukum bagi mereka yang belum mampu melaksanakan tugas pokoknya, sebab merekapun secara yuridis formal belum di-impassing menjadi tenaga fungsional penilik berdasarkan Keputusan Menpan.

Berdasarkan kenyataan yang ditemui di lapangan, khusus kemampuan penilik yang belum diimpassing pada umumnya belum optimal. Hal tersebut disebabkan mereka kurang diberi tanggung jawab, dan mereka menganggap kurang diperhatikan oleh Pemda baik mengenai impassing maupun kesejahteraannya. Salah satu upaya yang dilakukan mengatasi kurangnya kemampuan itu ialah dengan mengikutsertakan mereka dalam pelatihan fungsional dan teknis secara berkesinambungan.

\section{Kesiapan Pemerintah Daerah Provinsi Jawa Timur}

Pemerintah daerah yang telah siap umumnya telah memahami tentang arti pentingnya jabatan fungsional penilik dalam mendukung program PLS. Tenaga fungsional penilik diberikan kewenangan untuk menilik program PLS yang meliputi pendidikan masyarakat, pendidikan anak dini usia, kepemudaan dan olah raga.

Pada umumnya kesiapan pemerintah daerah meliputi antara lain: (1) adanya upaya pembenahan administrasi kepegawaian penilik, (2) merencanakan pembentukan Tim Penilai Angka Kredit, (3) memberikan tunjangan jabatan kependidikan, dan (4) adanya rencana pengembangan karir penilik.

\section{Faktor Pendukung dan Penghambat}

Faktor pendukung pelaksanaan Keputusan Menpan itu antara lain: (a) tersedianya anggaran yang diberikan untuk tunjangan tenaga kependidikan kepada 
para penilik yang telah di-impassing, dan (b) adanya kejelasan rencana pembinaan karir penilik yang dilakukan oleh Pemerintah Daerah. Sedangkan faktor penghambat antara lain: (a) pada umumnya para penilik yang telah di-impassing belum memiliki kemampuan dalam melaksanakan tugasnya, (b) belum jelas penentuan formasi jumlah penilik ahli dan terampil dikaitkan dengan beban kerja, dan (c) para penilik belum memiliki kemampuan menghitung perolehan angka kredit

\section{KESIMPULAN}

Berdasarkan hasil pembahasan di atas, dikemukakan beberapa kesimpulan sebagai berikut.

Pertama, keadaan penilik saat ini dalam posisi memprihatinkan, yang dicirikan oleh beberapa indikator yaitu: (a) rendahnya kemampuan profesional penilik dalam melaksanakan tugas pokok kepenilikan sesuai Keputusan Menpan No.15/KEP/MENPAN/3/2002, (b) rendahnya tingkat kesejahteraan penilik dan tunjangan kependidikan yang diperolehnya, dan (c) rasio jumlah penilik dan beban wilayah kerja yang kurang ideal sehingga menyulitkan mereka untuk menjangkau kepenilikan PLS secara cermat dan menyeluruh.

Kedua, secara umum Keputusan Menpan No. 15/KEP/MENPAN/3/2002 tentang Jabatan Fungsional Penilik dan Angka Kreditnya belum tersosialisasikan dengan baik di daerah-daerah kabupaten/kota di Provinsi Jawa Timur, dengan alasan: (a) lemahnya koordinasi dari pihak Pemerintah Pusat dengan Pemerintah Daerah sehubungan dengan diterbitkannya Keputusan Menpan tersebut; (b) tindak lanjut dari Pemerintah
Pusat untuk implementasi Keputusan Menpan tersebut, seperti penyediaan petunjuk teknis ataupun petunjuk pelaksanaan, belum tersosialisasi sampai ke daerah kabupaten/kota di Provinsi Jawa Timur, dan (c) ketidakpahaman Pemerintah Daerah Kabupaten/Kota (BKD dan Dinas Pendidikan) tentang Keputusan Menpan tersebut.

Ketiga, keberhasilan daerah melaksanakan kewenangannya memproses impassing penilik sangat tergantung pada peran yang dilakukan Dinas Pendidikan Kabupaten/Kota dan Badan Kepegawaian Daerah (BKD). Tidak adanya kesamaan persepsi dan koordinasi yang sinergis antara Dinas Pendidikan dan BKD tentang pentingnya keberadaan penilik dalam mendukung program pendidikan luar sekolah dan pemuda di wilayah kabupaten/kota Provinsi Jawa Timur yang merupakan faktor penghambat bagi proses impassing penilik, sehingga sampai saat ini masih sebagian besar Penilik belum di-impassing.

\section{DAFTAR PUSTAKA}

Cronbach, L. J. (1970). Essentials of psychological testing. New York: Happer and Row Publisher.

Gibson, J. L., Ivancevich, J. M. \& Donnefly, J. H. Jr. (1985). Organization behavior: Structureprocess. Rano Texas: Business Publications inc.

Robbins, S. P. (1998). Organizational behavior concepts, controversies and applications. New Jersey: Prentice-Hall International, Inc.

(1999). Undang-undang no. 22 tahun 1999 tentang pemerintahan daerah. Jakarta: Sinar Grafika.

(2000). Peraturan pemerintah Republik Indonesia no.99 tahun 2000 tentang kenaikan pangkat pegawai negeri sipil. Jakarta: Sinar Grafika.

(2000). Peraturan pemerintah no. 25 tahun 2000 tentang kewenangan pemerintah dan kewenangan provinsi sebagai daerah otonom. Jakarta: Sinar Grafika.

(2000). Peraturan pemerintah no. 84 tahun 2000 tentang pedoman organises perangkat daerah. Jakarta: Sinar Grafika.

(2002). Kepmenpan no.15/KEP/MENPAN/3/2002. jabatan fungsional penilik dan angka kreditnya. Jakarta: Lembaran Negara.

(2003). Undang-undang Republik Indonesia no.20 tahun 2003 tentang sistem pendidikan nasional. Jakarta: Biro Hukum dan Organisasi.

(2005). Peraturan pemerintah Republik Indonesia no. 19 tahun 2005 tentang standar nasional pendidikan. Jakarta: Badan Standar Nasfonal Pendidikan. 